\title{
A new species of Metapocrytus (Curculionidae: Entiminae: Pachyrhynchini) from Southern Mindanao, Philippines
}

\author{
Romeo R. Patano Jr., 1,2, Alman B. Mohagan ${ }^{1,2}$, Victor B. Amoroso ${ }^{1,2}$, Fulgent P. Coritico ${ }^{1,2}$ and \\ Sheryl A. Yap ${ }^{3, *}$
}

\begin{abstract}
Owing to the flightless behaviour of the Pachyrhynchini, new species are still being discovered in unexplored parts of the region. Hence, we described a new species: Metapocyrtus bronsi sp. nov. discovered in Mount Hamiguitan Range Wildlife Sanctuary, Davao Oriental, Mindanao, Philippines. Habitat, ecology, and threats are also described.
\end{abstract}

Keywords: curculionid, Mount Hamiguitan, new species, terminalia, the Philippines

\section{Introduction}

The Philippines is considered as one of the megadiverse countries with a very high species endemicity and richness of flora and fauna (Mittermeier et al., 1998), but there yet remain regions that are less explored such as Mindanao. Albeit several explorations conducted in the different forest and mountain ecosystems in the Mindanao regions (Ballentes et al., 2006; Cabras et al., 2016, 2017; Mohagan et al., 2018), its vast land and rich mountainous areas are yet to be investigated. One of the unexplored forested areas of known mountain range on the island is the Mount Hamiguitan Range Wildlife Sanctuary, Tumalite, San Isidro, Davao Oriental. This forest area is located in the western part of Mount Hamiguitan which is one of the proposed protected expansion sites. As the only UNESCO World Heritage Site in Mindanao, this area is very vital as the

\footnotetext{
${ }^{1}$ Center for Biodiversity Research and Extension in Mindanao (CEBREM), and ${ }^{2}$ Department of Biology, College of Arts and Sciences, Central Mindanao University, Musuan, Bukidnon 8710, Philippines

${ }^{3}$ Institute of Weed Science, Entomology, and Plant Pathology, College of Agriculture and Food Science, University of the Philippines Los Baños, Laguna 4031, Philippines
}

*Corresponding email: romeonojrpatano@gmail.com \& sayap3@up.edu.ph

Date Submitted: 06 July 2020

Date Accepted: 12 October 2020 remaining habitat of endemic and rare species of flora and fauna in the region. It harbors thousands of species which mostly are still unknown and just waiting to be discovered.

Pachyrhynchini are flightless and attractive weevils that can be found in areas where there is rich tropical vegetation in less explored mountainous regions between 500-2000 m above sea level and between the 16 and 18 north latitudes (Schultze, 1923; Yap \& Gapud, 2007). This group of weevils is easily recognized by their geniculate antennae, presence of broad rostrum, fully enclosed prothorax, fused elytra covering the whole pterothorax and abdomen, apically lobulated femora, and a wide-ranging colorful metallic scales, deep black body, and an array of patterns (Schultze, 1923, 1925).

One group that is largely unknown in Mindanao region is the genus Metapocyrtus, the most diverse and complex genus in the tribe Pachyrhynchini, with more or less 300 species that have unique and colorful body designs (Yap, 2008). The recent discovery of new species of Metapocyrtus weevils came from the island of Mindanao, namely $M$. kitangladensis, $M$. ginalopezae, M. tagabawa, M. pulangi and M. latifasciatus (Cabras et al., 2019; Cabras \& Medina, 2019; Bollino et al., 2020). These species add to more than hundreds of species in this genus.

Despite these new species discoveries, there are remaining undescribed weevil species inhabiting isolated forest and mountain ecosystems in Mindanao. Recent surveys on Mount Hamiguitan Range Wildlife Sanctuary have revealed species new to science and here, we describe a new species of Pachyrhynchini: Metapocyrtus (Artapocyrtus) bronsi sp. nov. with notes on their habitat, ecology, and threats. 


\section{Materials and Methods}

\section{Entry protocol and permits}

The research study was first presented to local stakeholders to obtain Prior Informed Consent. Compulsory permits such as an approved Gratuitous Permit (GP) from the Department of Environment and Natural Resources in compliance to R.A. 9147 for the collection of the specimens and Institutional Animal Care and Use Committee (IACUC) Permit for animal handling were then obtained.

Field sampling, collection of specimens, photography, and measurements

The species was collected in the lowland secondary forest of Mount Hamiguitan Range Wildlife Sanctuary, Tumalite, San Isidro, Davao Oriental (6²'’21.0'N, 12609'04'E; 845 masl; 03-11 February 2018) (Fig. 1). The combination of standard belt-transect, opportunistic and random sampling method was implemented in the study. The collection of species was conducted along an established $2 \mathrm{~km}$ transect covering $10 \mathrm{~m} \times 5$ $\mathrm{m}$ on both sides. Female specimens were collected through handpicking whenever encountered during the diurnal (07:00$15: 00 \mathrm{H})$ and nocturnal (17:00-22:00H) period. Specimens were then put in vials filled with $95 \%$ ethyl alcohol for preservation. Specimens were air-dried and mounted. Images of the species were taken using a DSLR Canon camera combined with a Labomed stereomicroscope. A licensed Adobe Photoshop CS software was used to produce final images of the species. The ocular micrometer was used to measure the specimens. The standard methodology of measurements by Yoshitake (2012) was employed.

Following measurements were taken: BL- Body length (from the apical margin of pronotum to the apex of the elytra), EL- elytral length (from the level of the basal margins to the apex of the elytra), WE- maximum width across elytra, PLpronotal length (from the base to apex along the midline), WPmaximum width across pronotum, RL- rostrum length and WRmaximum width of the rostrum.

The type specimens collected and examined in this study were deposited in Central Mindanao University, University Museum, Zoological Section, Curculionidae collection. All measurements are shown in millimeters. Paratypes: 5 females, same data as the holotype (All at Central Mindanao University, University Museum, Zoological Section).

\section{Taxonomy}

Metapocyrtus bronsi Patano \& Yap sp. nov. (Figs. 2-3) LSID: 1169F015-5290-486A-92B9-D0D3E0684C1D

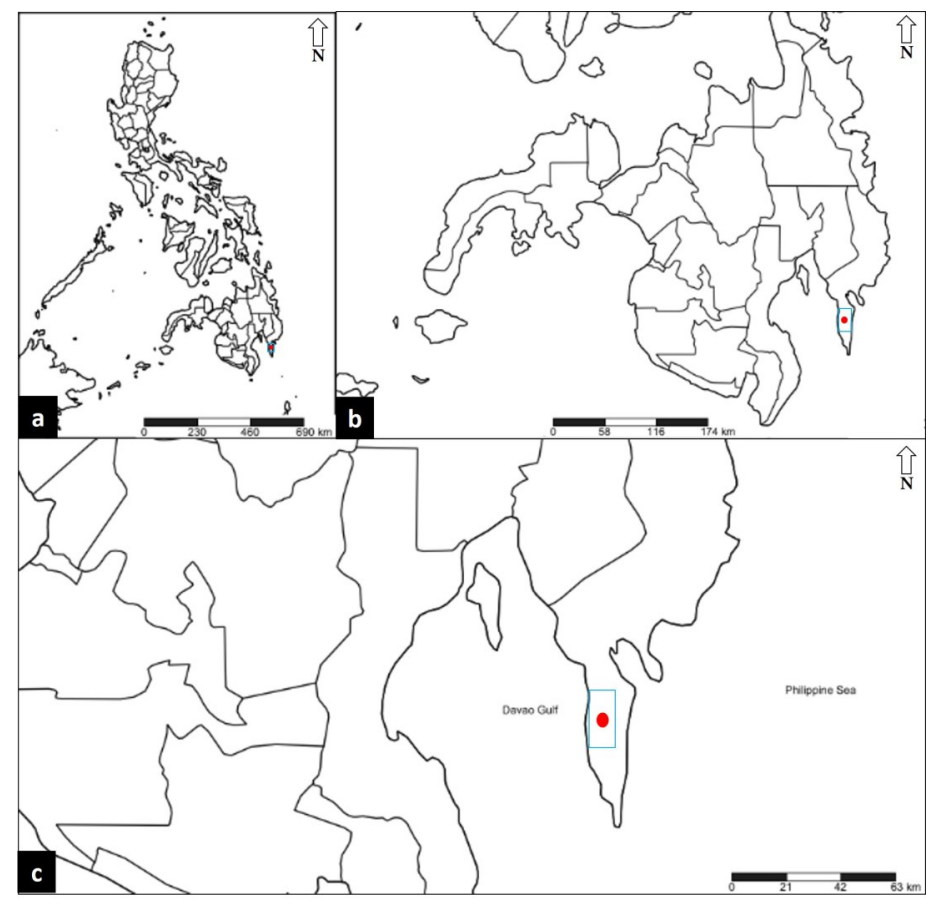

Figure 1. Map of the (a) Philippines and (b) Mindanao showing (c) Mount Hamiguitan, Tumalite, San Isidro, Davao Oriental $\left(6^{\circ}\right.$ 42 '21.0'N, $126^{\circ} 09^{\prime} 04$ ''E; 845 masl) where the specimens of the new species were collected (red dots).

Materials examined. Holotype, male (Figs. 2A-B): PHILIPPINES: Mindanao, Mount Hamiguitan Range Wildlife Sanctuary, Tumalite, San Isidro, Davao Oriental, 642'21.0”N, 12609'04”E, 845 masl, 04-11 February 2018, coll. A.B. Mohagan, R.R. Patano Jr. and V.B. Amoroso (Central Mindanao University, University Museum, Zoological Section).

Paratypes: 5 females, same data as the holotype (Central Mindanao University, University Museum, Zoological Section)

Diagnosis. The new species differs from all known congeners by the presence of yellow gold to bronze scale markings with green to blue scales scattered at the edge of the markings in elytra and pronotum, and legs entirely black. Elytra oblongovate, coarsely striate-punctate similar with Metapocyrtus (Artapocyrtus) humeralis and M. (A.) humeralis aureofasciatus. Position of transverse bands in the elytra similar with $M$. (A.) humeralis and $M$. (A.) humeralis aureofasciatus but differs in the color of scales.

Description. Measurements $\quad(\mathrm{n}=5)$ : $\quad$ BL: $\quad 9.9-11.2 \quad(10.5$ holotype). EL: 6.2-7.4 (7.4 holotype). WE: 4.2-5.3 (4.9 holotype). PL: 3.0-3.3 (3.0 holotype). WP: 3.4-4.0 (3.6 holotype). RL: 1.4-2.2 (2.1 holotype). WR: 1.1-1.8 (1.7 holotype).

Integument black. Body surface mostly shiny except 

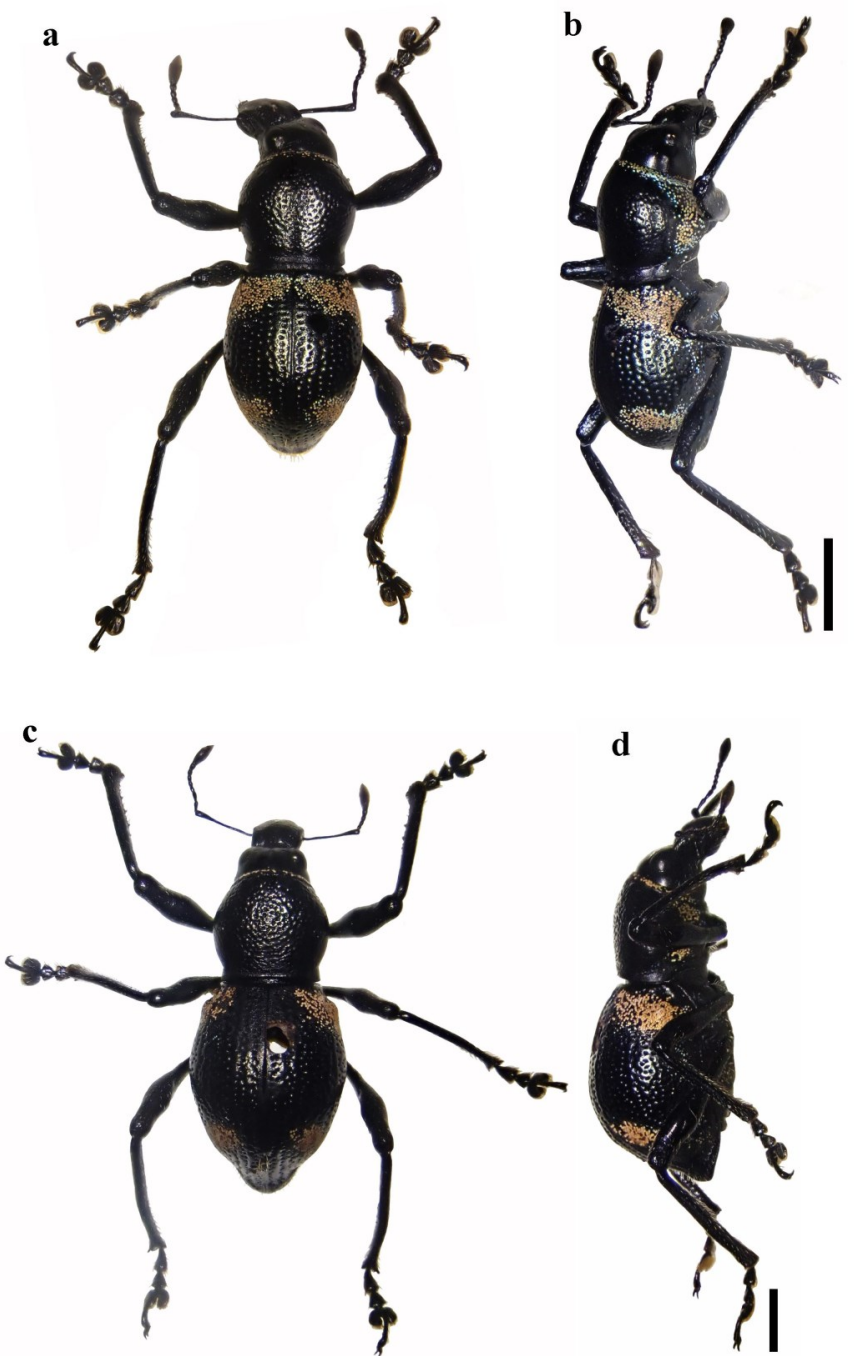

Figure 2. Metapocyrtus bronsi sp.nov. habitus male (a,b), female (c,d), dorsal $(a, c)$ and lateral $(b, d)$ views. Scale bars $=4 \mathrm{~mm}$.

underside with weaker luster.

Body mostly coarsely punctured, with markings of glossy recumbent round to oval scales, more or less mingled with minute hairs and scales. Head sparsely minutely pubescent without markings. Eyes, antennae and tarsomeres black. Eyes small and weakly convex. Antennal scape smaller compared to funicle plus club (2:3). Funicular with 7 segments. The I and II segments in same sizes $(0.6 \mathrm{~mm})$. Three times as long as wide. The last 5 segments same in sizes but three times shorter as the I and II segments $(0.2 \mathrm{~mm})$. Club of the antennae almost $1 \mathrm{~mm}$ in length and $0.4 \mathrm{~mm}$ in width, subellipsoidal in shape and almost covered with brown setae. Rostrum rugose, longer than wide, flattened dorso-apically with white setae and long yellow hairs towards apex with prominent transverse basal and longitudinal median grooves forming a cross shape. Ventral and lateral side with scattered short hairs. Pronotum globe-shaped, very weakly
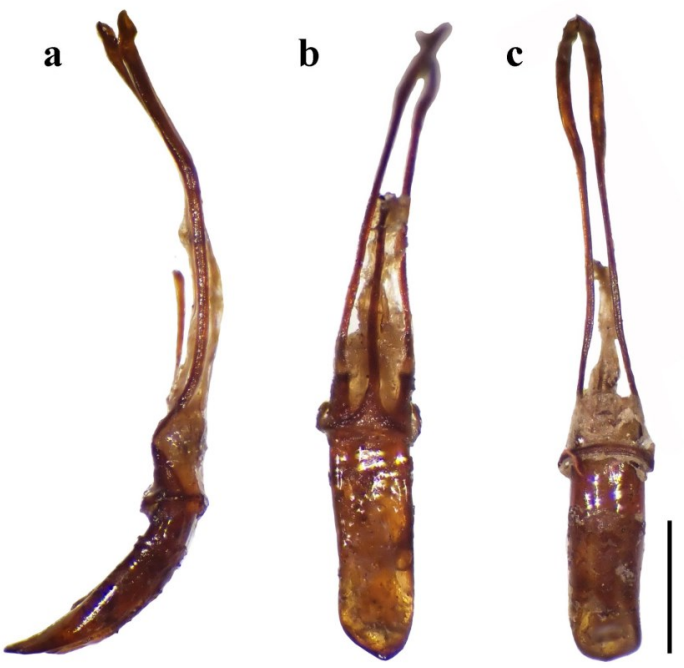

d
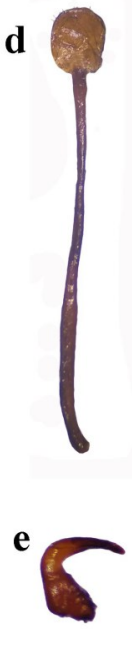

Figure 3. Metapocyrtus bronsi sp.nov. male genitalia in lateral (a), ventral (b), dorsal (c), sternite VIII in ventral (d) views, and spermatheca (e). Scale bar $=1 \mathrm{~mm}$.

convex, dorsally and coarsely irregularly punctate. An irregular yellow gold to bronze with scattered blue scale band at anterior margin confluent to the large-scale spot at each lateral margin, the latter reaching to base. Elytra oblong-ovate, coarsely striatepunctate. Each elytron with broad transverse yellow gold to bronze, green to blue scales band at anterior and posterior third, both bands confluent along lateral margin with an irregular marginal stripe. Female, some specimens with few to none, green to blue irregular marginal stripe along lateral margin. Ventral side black with white setae. Sparse sky-blue to gold scales present at both sides of the abdomen. Legs black with white short hairs. Fore and mid femora almost $4 \mathrm{~mm}$ long and 1 $\mathrm{mm}$ in width. Tibiae armed with tooth-like projections at the inner margin covered with short setae. Tarsomeres covered with brown sparse setae. Genitalia as photographed (Fig. 3).

Etymology. The new species is named after the Mandaya word "bronsi" meaning bronze, the prominent color of the scale markings on the integument.

Habitat, ecology and threats. The species is collected in the buffer zone of Mount Hamiguitan characterized as lowland secondary forest (Fig. 4). The species was observed perching on leaves of Sphaeropteris polypoda and Dillenia philippinensis. This secondary forest is dominated by ferns species such as Taenitis blechnoides, Selaginella jagorii, S. polypoda, Schizaea dichotoma, Pteridium aquilinum and trees species such as Macaranga sp., Teijsmanniodendron ahernianum, Lithocarpus woodii, Ochrosia glomerata, O. apoensis, Artocarpus 


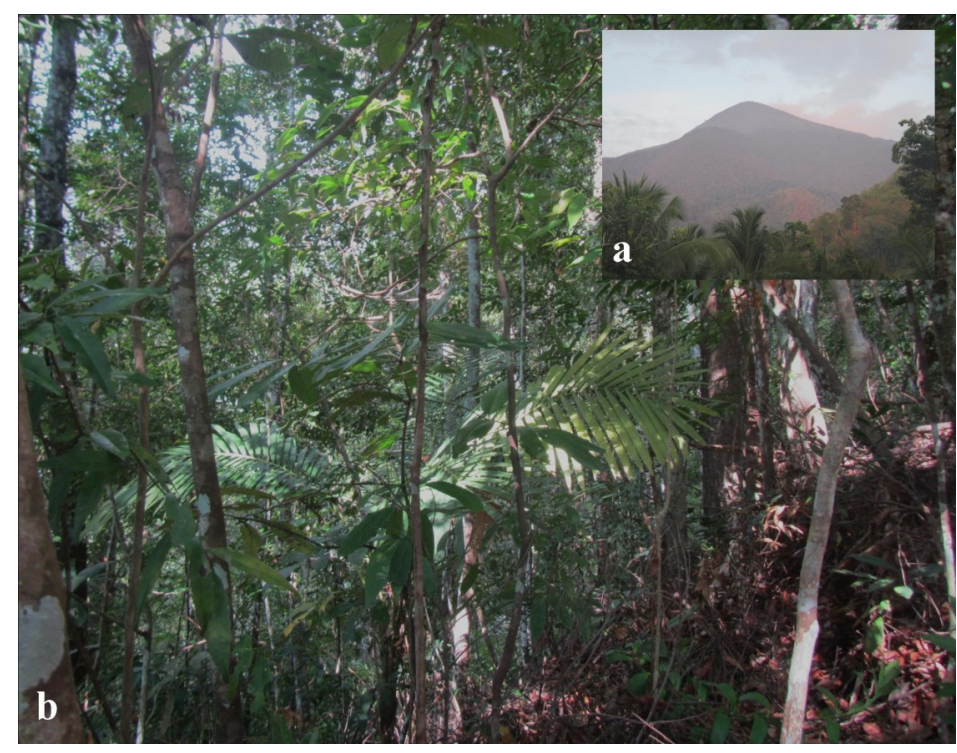

Figure 4. Habitat of the Metapocyrtus bronsi sp. nov., a lowland secondary rainforest about 845 masl (b) in Mt. Hamiguitan (a).

multifidus, Streblus elongatus, Buchanania arborescens, Greeniopsis multiflora, Shorea astylosa, Gymnostoma rumphianum and Syzygium spp. Mount Hamiguitan has a total land area of $169.23 \mathrm{~km}^{2}$ with the highest elevation of 1,637 masl and characterized by a variety of vegetation types including a unique mossy pygmy forest (UNESCO, 2014; Amoroso et al., 2009). Although this mountain ecosystem is under protection by under R.A. 9303 of July 30, 2004, following the objective of NIPAS Act of 1992 or R.A. 7586 (UNESCO, 2014), destructive anthropogenic activities are still happening in the area such as illegal logging of economically expensive trees (Aquilaria spp.) and agricultural activities.

\section{Acknowledgement}

The authors would like to sincerely thank the Department of Science and Technology Grants-in-Aid (DOST-GIA) program entitled "Biodiversity in Selected Mountain Ecosystems of Mindanao for Conservation and Sustainable Development" as the funding agency and to the Department of Environment and Natural Resources (DENR) for the issuance of Gratuitous Permit (GP). The authors would like also to acknowledge Central Mindanao University administration through the leadership of Dr. Jesus Antonio G. Derije, University President, for his valuable logistical support.

\section{Literature Cited}

Amoroso, V.B., L.D. Obsioma, J.B. Arlalejo, R.A. Aspiras, D.P. Capili, J.A.A. Polizon \& E.B. Sumile, 2009.
Inventory and conservation of endangered, endemic and economically important flora of Hamiguitan Range, Southern Philippines. Blumea, 54(1-3): 71-76.

Ballentes, M., A. Mohagan, V. Gapud, M.C. Espallardo \& M. Zarcilla, 2006. Arthropod Faunal Diversity and Relevant Interrelationships of Critical Resources in Mt. Malindang, Misamis Occidental. Southeast Asian Regional Center for Graduate Study and Research in Agriculture (SEARCA) 1 -166 .

Bollino, M., M.N. Medina \& A. Cabras, 2020. Three new Metapocyrtus Heller, 1912 (Curculionidae, Entiminae, Pachyrhynchi) from Mindanao Island, Philippines. Journal of Tropical Coleopterology, 1(1): 26-38.

Bollino, M. \& F. Sandel, 2015. Three new species of the genus Pachyrynchus Germar, 1842 from Lubang Island (Philippines) (Coleoptera: Curculionidae: Pachyrynchini). Munis Entomology and Zoology Journal, 10(2): 392-401.

Cabras, A., F. Coritico, A. Mohagan \& A. Rukmane, 2017. Diversity of Pachyrynchini (Coleoptera: Curculionidae: Entiminae) in Mt. Kiamo, Malaybalay, Bukidnon, Mindanao, Philippines. Journal of Entomology and Zoology Studies, 5(3): 979-983.

Cabras, A.A. \& M.N. Medina, 2019. Metapocyrtus ginalopezae sp. n., a new Orthocyrtus from Davao de Oro, Mindanao Island. Baltic Journal of Coleopterology, 19(1): 205-211.

Cabras, A.A., M.N.D. Medina \& G. Zhang, 2019. Metapocyrtus kitangladensis sp. n., a new Pachyrhynchus cumingii GR Waterhouse, 1841 mimic from Mindanao Island, Philippines. Zookeys, 853: 119-129.

Cabras, A., G. Nique \& A. Mohagan, 2016. Diversity and distribution of Pachyrynchini (Coleoptera: Curculionidae: Entiminae) in Mt. Apo, Natural Park, Philippines. Journal of Biodiversity and Environmental Science, 8(2): 312-319.

Medina, M.N.D. \& A.A. Cabras, 2018. Metapocyrtus (Artapocyrtus) willietorresi sp. n. (Coleoptera: Curculionidae) from Southern Mindanao (Philippines), with notes on its ecology and mimicry complex. Baltic Journal of Coleopterology, 18(2): 185-192.

Mittermeier, R.A., N. Myers, J.B. Thomsen, G.A.B. da Fonseca \& S. Olivieri, 1998. Biodiversity hotspots and major tropical wilderness areas: approaches to setting conservation priorities. Conservation Biology, 12: 516520.

Mohagan, A.B., R.P. Patano Jr, A. Hongco, N. Lagunday, F. Coritico \& V.B. Amoroso, 2018. Species occurrence of weevils (Coleoptera: Curculionidae) in the Baganihan, Marilog Forest Reserve, Marilog District, Davao City, Philippines. Journal of Biodiversity and Environmental Sciences, 13(2): 30-34. 
Schultze, W., 1923. A monograph of the Pachyrrhynchid group of the Brachyderinae, Curculionidae: Part I. Philippine Journal of Science, 23: 609-673 + 6 pls.

Schultze, W., 1925. A Monograph of the Pachyrrhynchid Group of the Brachyderinae, Curculionidae: Part III. The genera Apocyrtidius Heller and Metapocyrtus Heller. Philippine Journal of Science, 26: 131-309 + pls. I-XII.

United Nations Educational, Scientific and Cultural Organization [UNESCO], 2014. Nine new sites inscribed on World Heritage List. Retrieved 2018-01-05. http:// whc.unesco.org

Yap, S.A., 2008. Checklist of the Metapocyrtus Complex (Curculionidae: Entiminae: Pachyrrhynchini) of the Philippines. Asia Life Sciences, 17(2): 249-260.

Yap, S.A. \& V.P. Gapud, 2007. Taxonomic review of the genus Metapocyrtus Heller (Coleoptera: Curculionidae: Entiminae). The Philippine Entomologist, 21(2): 115-135.

Yoshitake, H., 2012. Nine new species of the genus Pachyrhynchus Germar (Coleoptera: Curculionidae) from the Philippines. Esakia, (52): 17-34. 